\title{
Ultrasound-Targeted Microbubble Destruction-Mediated Inhibition of Livin Expression Accelerates Ovarian Cancer Cell Apoptosis
}

\author{
Xiaolin Xu, ${ }^{1}$ Shuqin Yu, ${ }^{1}$ Xiaoyuan Liu, ${ }^{1}$ and Ying Feng $\mathbb{D}^{2}$ \\ ${ }^{1}$ Department of Obstetrics and Gynecology, Shangrao Municipal Hospital, Shangrao, Jiangxi 334000, China \\ ${ }^{2}$ Department of Obstetrics and Gynecology, The Second Affiliated Hospital of Nanchang University, Nanchang, \\ Jiangxi 330006, China
}

Correspondence should be addressed to Ying Feng; ndefy05043@ncu.edu.cn

Received 5 November 2021; Accepted 29 November 2021; Published 9 December 2021

Academic Editor: Enfa Zhao

Copyright (c) 2021 Xiaolin Xu et al. This is an open access article distributed under the Creative Commons Attribution License, which permits unrestricted use, distribution, and reproduction in any medium, provided the original work is properly cited.

Objective. Ultrasound-targeted microbubble destruction (UTMD) technique has recently been developed as a nonviral delivery of gene therapy. This study aimed at investigating the survival and apoptosis of ovarian cancer cell line OVCA-433 by inhibiting Livin expression through ultrasound-targeted microbubble destruction. Methods. We synthesized a targeted microbubble agent for UTMD-mediated shRNA against Livin gene in human ovarian cancer OVCA-433 cells. Lipid microbubbles were conjugated with a luteinizing hormone-releasing hormone analog (LHRHa) by an avidin-biotin linkage to target the ovarian cancer OVCA433 cells expressing LHRH receptors. The microbubbles were mixed with the recombinant plasmid harboring shRNA-Livin. shRNA-Livin was transfected into OVCA-433 cells upon exposure to $1 \mathrm{MHz}$ pulsed ultrasound beam $\left(0.5 \mathrm{~W} / \mathrm{cm}^{2}\right)$ for $8 \mathrm{~s}$. Cell survival was measured by the MTT assay, cell apoptosis by flow cytometry using annexin V/PI double staining, and cell ultrastructure by using the transmission electron microscope. The mRNA and protein expression levels of caspase- 3 and caspase- 8 were detected by RT-qPCR and western blotting. Results. UTMD-mediated delivery of shRNA-Livin remarkably reduced the survival of OVCA-433 cells but promoted the apoptosis compared with shRNA-Livin alone, shRNA-Livin plus nontargeted microbubbles, and shRNA-Livin plus LHRHa-conjugated microbubbles containing shRNA-Livin with or without exposure to ultrasound pulses. It was also found that UTMD-mediated delivery of shRNA-Livin notably declined the mRNA and protein expression levels of caspase-3 and caspase- 8 in OVCA-433 cells compared with shRNA-Livin alone, shRNA-Livin plus nontargeted microbubbles, and shRNA-Livin plus LHRHa-conjugated microbubbles containing shRNA-Livin with or without exposure to ultrasound pulses. Conclusion. Our experiment verifies the hypothesis that ultrasound mediation of targeted microbubbles can enhance the transfection efficiency of shRNA-Livin in ovarian cancer cells.

\section{Introduction}

Ovarian cancer usually originates from the fallopian tube rather than the ovary. It refers to the epithelial cancer of the ovary or fallopian tube, as well as the histologically similar primary peritoneal cancer [1]. Ovarian cancer, known as the silent killer, is associated with 150,000 deaths in 2012, ranking eighth among the causes of cancer death in women [2]. Actually, more than $70 \%$ people who suffered from ovarian cancer are not diagnosed until the late stage due to the lack of effective screening tool, as well as vague symptoms, resulting in difficulty in cure [3]. It has been reported that the people with ovarian cancer were with $47.4 \%$ five-year survival [4]. The prevalence of ovarian cancer is positively correlated with age. Women under 40 years of age are more likely to have high probability of ovarian germ cell tumor rather than ovarian cancer. Ovarian cancer is common among women over the age of 40 especially in developed countries, which is the second most common malignancy after breast cancer among this group $[5,6]$.

At present, surgical resection of high-risk tissues is the most successful strategy in the treatment of ovarian cancer 
[7]. However, some reports indicated that surgery applied to advanced ovarian cancer frequently leads to serious postoperative complications, which directly affect survival $[8,9]$. Therefore, it is of great significance to explore new treatments for ovarian cancer. The study found that abnormal expression of genes regulating cell apoptosis affects the occurrence and development of tumors [10, 11]. Inhibitor of apoptosis (IAP) family is antiapoptotic proteins with 70 amino acid baculovirus repeats [12] and involved in negative regulation of apoptosis $[13,14]$. Livin, as a new important member of the IAP family proteins, is highly expressed in a variety of tumor cells, participates in the inhibition of cell apoptosis, and is closely related to the occurrence and development of tumors $[15,16]$. The upregulation of Livin was found both in primary specimens from ovarian cancer patients and in ovarian cancer cell lines compared to normal controls. Overexpression of specific Livin transcripts promoted cell viability and migration, whereas Livin knockdown repressed these cellular processes. These effects of the Livin gene were also confirmed in a xenograft mouse model [15]. Ultrasound is the second most widely used imaging method worldwide. With the rapid development of ultrasound technology and material science, ultrasound contrast agent has expanded from the traditional diagnostic field to the therapeutic field. Ultrasound combined with appropriate delivery systems to target sites has been widely utilized [17]. Microbubbles with diameter $1-7 \mu \mathrm{M}$ are used as ultrasonic contrast agents, enhancing ultrasonic backscattered signals. The therapeutic drug coated by microbubbles is able to reach the target sites and then release $[18,19]$. Streptavidin-biotin technology using microfluidic devices is effective in the synthesis of targeted lipid microbubbles, with precise size and high monodispersity than common lipid microbubbles prepared by DPPD and DSPE [20].

In the present study, lipid microbubbles bind to LHRHa targeting Livin, prepared by Shanghai Genechem Co., Ltd., which was applied to ovarian cancer cell OVCA- 433. However, the low entrapment efficiency of the lipid microbubbles results in a lack of sufficient plasmid in the transfection process; hence, the microbubbles were mixed with an appropriate amount of plasmids for this research. This study aimed at exploring the inhibition effect of ultrasound-targeted microbubble destruction in Livin expression affecting apoptosis of ovarian cancer cell line OVCA-433 and providing reference for gene therapy in ovarian cancer.

\section{Materials and Methods}

2.1. OVCA-433 Cell Culture and Grouping. OVCA-433 cell line (Shanghai Suer Biotechnology Co., Ltd., China) was cultured in the DMEM (Tongpai Biotechnology Co., Ltd., Shanghai, China) containing $10 \%$ fetal calf serum (FBS), $100 \mathrm{U} / \mathrm{ml}$ penicillin, and $100 \mu \mathrm{g} / \mathrm{ml}$ streptomycin at $37^{\circ} \mathrm{C}$ in an incubator with $5 \% \mathrm{CO}_{2}$. When cells came to their logarithmic phase of growth, cell suspension $\left(1 \times 10^{6}\right.$ cells $\left./ \mathrm{mL}\right)$ was placed in the 24-well culture plate, and each well was added with $50 \mu \mathrm{L}$. Afterward, OVCA- 433 cells were assigned into blank, shRNA-Livin (transfection of shRNA-Livin alone), shRNA-Livin-NMB (shRNA-Livin plus nontargeted microbubbles), shRNA-Livin-TMB (shRNA-Livin plus LHRHa-conjugated microbubbles containing shRNALivin), shRNA-Livin + US (shRNA-Livin transfection followed by ultrasound destruction), shRNA-Livin-NMB + US (the mixture of shRNA-Livin and NMBs followed by ultrasound destruction), and shRNA-Livin-TMB + US (the mixture of shRNA-Livin and TMBs followed by ultrasound destruction) groups. The concentration of lipid microbubbles was $0.6 \times 10^{8} / \mathrm{mL}$. For ultrasound destruction, a $1 \mathrm{MHz}$ piezoelectric ceramic transducer was immersed $2 \mathrm{~mm}$ above the cell suspension within the cell culture medium. Ultrasound pulses with an averaged intensity of $0.5 \mathrm{~W} / \mathrm{cm}^{2}$ were applied to the medium for $8 \mathrm{~s}$. Following exposure of the ultrasound pulses, the cells were seeded in a 24-well plate and incubated for $24 \mathrm{~h}$.

\subsection{Preparation of Nontargeted Lipid Microbubbles (NMBs).} 1,2-Dipalmitoyl-sn-glycero-3-phosphocholine (DPPC) and 1,2-distearoyl-sn-glycero-3-phosphoethanolamine (DSPE) were dissolved in $50 \mu \mathrm{l}$ glycerol at a ratio of $10: 1$ (5 mg: $0.5 \mathrm{mg}$ ). After adding with $450 \mu \mathrm{l}$ phosphate-buffered saline (PBS), the mixture was placed in a $40^{\circ} \mathrm{C}$ water bath for $30 \mathrm{~min}$ and then refilled with perfluorobutane gas for shaking $45 \mathrm{~s}$. The generated NMBs were washed with $0.5 \mathrm{ml}$ PBS and stored at $-20^{\circ} \mathrm{C}$.

2.3. Preparation of Targeted Lipid Microbubbles (TMBs). DPPC and DSPE-PEG2000-biotin were dissolved in $50 \mu \mathrm{l}$ glycerol at a ratio of $10: 1$ to biotinylate lipid microbubbles. Next, $1 \mu \mathrm{l}$ biotinylated lipid microbubbles were adjusted into $1 \times 10^{8} / \mathrm{ml}$, and then $100 \mu \mathrm{l}$ microbubbles were diluted into $1 \mathrm{ml}$ in PBS. After centrifugation at $1000 \mathrm{rpm}$ for $3 \mathrm{~min}$, the supernatant was added with $60 \mu \mathrm{g}$ FITC-labeled streptavidin and underwent low-speed shake (180 cycles/min) for $20 \mathrm{~min}$. After centrifugation at $1000 \mathrm{rpm}$ for $3 \mathrm{~min}$ again, the supernatant was collected as avidinylating lipid microbubbles. The avidinylated microbubbles were conjugated with 50 biotinylated LHRHa peptides. The mixture of $10 \mu \mathrm{l}$ LHRHaconjugated lipid microbubbles and $100 \mu \mathrm{l}$ poly-L-lysine was added with $1.6 \mu \mathrm{g}$ shRNA-Livin and incubated for $30 \mathrm{~min}$. After PBS washing and centrifugation, TMBs were purified and stored at $-20^{\circ} \mathrm{C}$.

2.4. Cell Survival Assays. OVCA-433 cell survival was evaluated using MTT assays. In brief, cell suspension (logarithmic phase) was set as a concentration of $1 \times 10^{6} \mathrm{cell} / \mathrm{ml}$, detached by trypsase, supplemented with DMEM, and then placed into the 96-well culture plate with $150 \mu \mathrm{L}$ in each well. Three replications were prepared for each group. After $24 \mathrm{~h}$ incubation in the $5 \% \mathrm{CO}_{2}$ incubator at $37^{\circ} \mathrm{C}$, each well was added with $10 \mu \mathrm{l}$ MTT $(5 \mathrm{mg} / \mathrm{ml})$ and cultured for another $4 \mathrm{~h}$. With the supernatant removed, each well was added with $100 \mu \mathrm{l}$ DMSO and shook by an oscillator at low speed for $10 \mathrm{~min}$. The OD value was measured at the wavelength of $492 \mathrm{~nm}$ detected, and cell survival rate was calculated. 
2.5. Cell Apoptosis Assays. In brief, the cells were harvested with trypsin $(0.25 \%)$, washed twice with PBS, and adjusted into $1 \times 10^{6} \mathrm{cell} / \mathrm{ml}$. OVCA-433 cell apoptosis was determined by annexin V/PI double staining in strict accordance with the instructions of the kit (Shanghai Kanglang Biotechnology Co., Ltd., China). Apoptotic index $=[$ (early apoptotic cells + late apoptotic cells)/total cells] $\times 100 \%$.

2.6. RNA Extraction and Real-Time Quantitative PCR (RT$q P C R)$. Total RNA of OVCA-433 cells in each group was extracted by the TRIzol method, and CDNA was generated by using a PrimeScript RT Reagent Kit (Takara, Dalian, China). RT-qPCR was performed with the SYBR ${ }^{\circledR}$ Premix Ex Taq ${ }^{\mathrm{TM}}$ II (Tli RNaseH Plus) kit (Takara) using a ABI PRISM ${ }^{\circledast} 7500$ System (Applied Biosystems, Foster City, CA, USA). Primer synthesis was completed by Synbio Technologies (Suzhou, Jiangsu, China). Primer sequences for Livin were as follows: upstream: $5^{\prime}$-GGTCATTACTGGAGTCTTG-3' and downstream: $5^{\prime}$-CACTTTAACAATAGGCGAGT-3' ; for caspase3: upstream: $5^{\prime}$-CTGATCCACAGGAGATATTA- $3^{\prime}$ and downstream: $5^{\prime}$-CAATAATGCTGTAAAACCTT- ${ }^{\prime}$; for

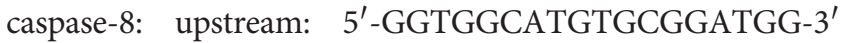
and downstream: $5^{\prime}$-TTCAACGGTGAGGTCACG-3'; for GAPDH: upstream: 5'-TTCGACAGTCAGCCGCATCTT-3' and downstream: $5^{\prime}$-CCCAATACGACCAAATCCGTT- $3^{\prime}$. The reaction system adopted 40 cycles, which included $2 \mathrm{~min}$ of predenaturing at $94^{\circ} \mathrm{C}, 30 \mathrm{~s}$ of annealing at $94^{\circ} \mathrm{C}, 30 \mathrm{~s}$ of extension at $52^{\circ} \mathrm{C}$, and $1 \mathrm{~min}$ of extension at $72^{\circ} \mathrm{C}$. The relative expressions of Livin, caspase- 3 , and caspase- 8 mRNA were calculated using $2^{-\Delta \Delta \mathrm{Ct}}$ methods with GAPDH mRNA expression as the internal reference.

2.7. Western Blotting. The total protein of OVCA- 433 cells in each group was extracted by RIPA lysis buffer and quantified by the BCA method. The protein was separated by SDS-PAGE and wet-transferred onto the PVDF membrane. The PVDF membrane was sealed using 5\% skimmed milk powder for $1 \mathrm{~h}$, probed with anti-Livin antibody (ab236500, Abcam, Cambridge, UK), anti-caspase- 3 antibody (ab32351, Abcam), anti-caspase-8 antibody (ab32397, Abcam), and anti-GAPDH antibody (ab8245, Abcam) overnight at $4^{\circ} \mathrm{C}$, and then reprobed with secondary antibody $\operatorname{IgG}$ conjugated with HRP. Western blots were rinsed with TBST buffer for 3 times and reacted with ECL solutions.

2.8. Statistical Analysis. SPSS 20.0 software was used for data analysis. Data were expressed as mean \pm standard deviation, and $t$-test was performed for two-group comparison, oneway ANOVA for multiple-group comparison, and two-way ANOVA for comparison at different time points. $P<0.05$ was considered as statistically significant.

\section{Results}

3.1. UTMD Enhanced the Inhibition of ShRNA-Livin on OVCA-433 Cell Survival. The cell survival rates of each group were calculated at indicated culture time points, 24 ,
48 , and $72 \mathrm{~h}$ (Table 1 ). After culture for $24 \mathrm{~h}$, the cell survival rates in the shRNA-Livin-TMB, shRNA-Livin + US, shRNALivin-NMB + US, and shRNA-Livin-TMB + US groups were lower than those in the blank, shRNA-Livin, and shRNALivin-NMB groups $(P<0.05)$; after culture for $48 \mathrm{~h}$, the cell survival rate in the shRNA-Livin-NMB group was lower than that in the blank and shRNA-Livin groups $(P<0.05)$; after culture for $72 \mathrm{~h}$, the cell survival rate in the shRNALivin group was lower than that in the blank group $(P<0.05)$, suggesting that UTMD enhanced the efficacy of shRNA-Livin to reduce OVCA-433 cell survival. The shRNA-Livin-TMB + US group exhibited the lowest cell survival rate among the 7 groups $(P<0.05)$, indicating that UTMD enhanced the inhibition of shRNA-Livin on OVCA433 cell survival.

3.2. UTMD Enhanced the Promotion of ShRNA-Livin on OVCA-433 Cell Apoptosis. After culture for $48 \mathrm{~h}$, it was found that the nucleus of OVCA-433 cells in the blank group was larger, with complete organelles seen in the cytoplasm under the transmission electron microscope. Early apoptosis represented by changes in the nucleolus and cytoplasm gathering under the nuclear membrane was noted in OVCA433 cells in the shRNA-Livin-TMB + US group. Results of flow cytometry using annexin V/PI double staining revealed the apoptosis rates of the blank, shRNA-Livin, shRNALivin-NMB, shRNA-Livin-TMB, shRNA-Livin + US, shRNA-Livin-NMB + US, and shRNA-Livin-TMB + US groups to be $3.41 \pm 0.37 \%, 6.15 \pm 0.54 \%, 6.29 \pm 0.81 \%$, $6.91 \pm 0.75 \%, 8.14 \pm 0.93 \%, 12.95 \pm 1.37 \%$, and $29.51 \pm 3.87 \%$, respectively. Compared with the blank group, the other 6 groups showed remarkable increases in OVCA-433 cell apoptosis rate $(P<0.05)$, and the shRNA-Livin-TMB + US group indicated much higher cell apoptosis rate compared to the shRNA-Livin, shRNA-Livin-NMB, shRNA-Livin-TMB, shRNA-Livin + US, and shRNA-Livin-NMB + US groups $(P<0.01$, Figure 1$)$. These data suggested that UTMD enhanced the promotion of shRNA-Livin on OVCA-433 cell apoptosis.

3.3. UTMD Enhanced the Increase of shRNA-Livin on Caspase- 3 and Caspase- 8 mRNA. As listed in Table 2, after $48 \mathrm{~h}$ of culture, the relative expressions of Livin mRNA were lower, but the relative expressions of caspase- 3 mRNA and caspase- 8 mRNA were higher in shRNA-Livin, shRNALivin-NMB, shRNA-Livin-TMB, shRNA-Livin + US, shRNA-Livin-NMB + US, and shRNA-Livin-TMB + US groups than those in the blank group $(P<0.05)$. The shRNALivin-TMB + US group indicated a lower expression of Livin mRNA and higher expressions of caspase- 3 mRNA and caspase- 8 mRNA compared to the shRNA-Livin, shRNALivin-NMB， shRNA-Livin-TMB， shRNA-Livin + US, and shRNA-Livin-NMB + US groups $(P<0.01)$.

3.4. UTMD Enhanced the Increase of shRNA-Livin on Caspase- 3 and Caspase- 8 Proteins. After $48 \mathrm{~h}$ of culture, the relative expressions of Livin protein were lower, but the 
TABLE 1: Cell survival rate of each group at different culture time points.

\begin{tabular}{lcrr}
\hline Group & $24 \mathrm{~h}(\%)$ & $48 \mathrm{~h}(\%)$ & $72 \mathrm{~h}(\%)$ \\
\hline Blank & $99.15 \pm 0.39^{(2)}$ & $98.39 \pm 0.55^{(2)}$ & $94.07 \pm 0.43^{(2)}$ \\
shRNA-Livin & $97.39 \pm 0.62^{(2)}$ & $94.51 \pm 0.90^{(2)}$ & $82.16 \pm 1.39^{(1)(2)}$ \\
shRNA-Livin-NMB & $96.42 \pm 0.80^{(2)}$ & $90.25 \pm 0.61^{(1)}$ & $75.43 \pm 0.82^{(1)(2)}$ \\
shRNA-Livin-TMB & $94.26 \pm 1.42^{(1)(2)}$ & $86.09 \pm 0.73^{(1)}$ & $70.27 \pm 1.04^{(1)(2)}$ \\
shRNA-Livin + US & $79.13 \pm 1.85^{(1)(2)}$ & $71.64 \pm 1.30^{(1)}$ & $47.81 \pm 2.71^{(1)(2)}$ \\
shRNA-Livin-NMB + US & $70.51 \pm 1.59^{(1)}$ & $55.17 \pm 1.88^{(1)}$ & $39.25 \pm 1.18^{(1)(2)}$ \\
shRNA-Livin-TMB + US & $58.37 \pm 2.15^{(1)}$ & $44.32 \pm 1.45^{(1)}$ & $24.49 \pm 1.06^{(1)}$ \\
\hline
\end{tabular}

${ }^{1} \mathrm{P}<0.05$ compared to the blank group; ${ }^{2} P<0.05$ compared to the shRNA-Livin-TMB + US group.
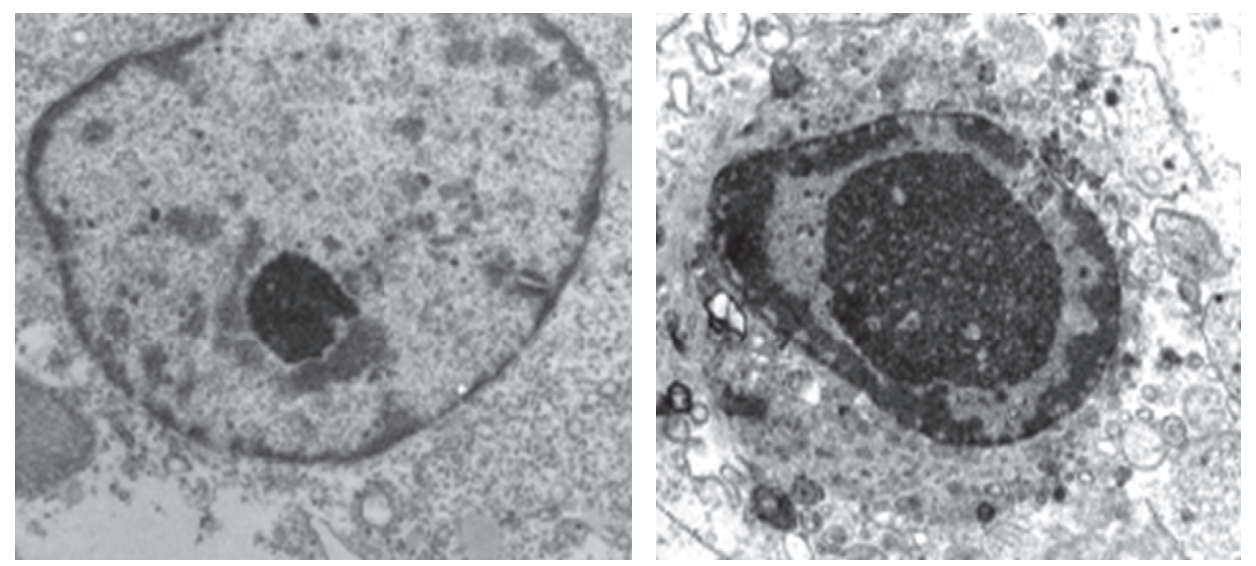

Figure 1: Cell ultrastructure $(\times 2000)$ of the blank group (a) and shRNA-Livin-TMB + US group (b).

TABLe 2: The mRNA expression levels of Livin, caspase-3, and caspase-8 in each group.

\begin{tabular}{|c|c|c|c|}
\hline Group & Livin & Caspase-3 & Caspase- 8 \\
\hline Blank & $4.95 \pm 0.35^{(2)}$ & $0.95 \pm 0.19^{(2)}$ & $1.50 \pm 0.15^{(2)}$ \\
\hline shRNA-Livin & $4.60 \pm 0.31^{(2)}$ & $1.13 \pm 0.15^{(2)}$ & $1.68 \pm 0.23^{(2)}$ \\
\hline shRNA-Livin-NMB & $4.43 \pm 0.23^{(2)}$ & $1.30 \pm 0.26^{2}$ & $1.83 \pm 0.21^{(2)}$ \\
\hline shRNA-Livin-TMB & $3.35 \pm 0.46^{(1)(2)}$ & $1.52 \pm 0.21$ (1) (2) & $2.25 \pm 0.27^{(1)(2)}$ \\
\hline shRNA-Livin + US & $2.49 \pm 0.15^{\text {(1) (2) }}$ & $2.76 \pm 0.18^{(1)(2)}$ & $3.62 \pm 0.35^{(1)(2)}$ \\
\hline shRNA-Livin-NMB + US & $2.06 \pm 0.13^{(1)(2)}$ & $3.15 \pm 0.47^{(1)(2)}$ & $3.95 \pm 0.31$ (1) (2) \\
\hline shRNA-Livin-TMB + US & $1.33 \pm 0.08^{(1)}$ & $4.38 \pm 0.45^{(1}$ & $5.08 \pm 0.63^{(1)}$ \\
\hline
\end{tabular}

${ }^{1} \mathrm{P}<0.05$ compared to the blank group; ${ }^{2} \mathrm{P}<0.05$ compared to the shRNA-Livin-TMB + US group.

relative expressions of caspase- 3 and caspase- 8 proteins were higher in shRNA-Livin, shRNA-Livin-NMB, shRNA-LivinTMB, shRNA-Livin + US, shRNA-Livin-NMB + US, and shRNA-Livin-TMB + US groups than those in the blank group $(P<0.05)$. The shRNA-Livin-TMB + US group indicated a lower expression of Livin protein and higher expressions of caspase- 3 and caspase- 8 proteins compared with the shRNA-Livin, shRNA-Livin-NMB, shRNA-LivinTMB, shRNA-Livin + US, and shRNA-Livin-NMB + US groups $(P<0.01$, Figure 2 and Table 3$)$.

\section{Discussion}

Ovarian cancer is the most lethal malignant tumor in gynecological tumors. The incidence rate of ovarian cancer is lower than endometrial cancer [21]. In 2012, about 145,000 deaths of ovarian cancer worldwide [2] were reported. Ovarian cancer is characterized by vague symptoms and low 5 -year survival rate. It was reported that $70 \%$ women died of

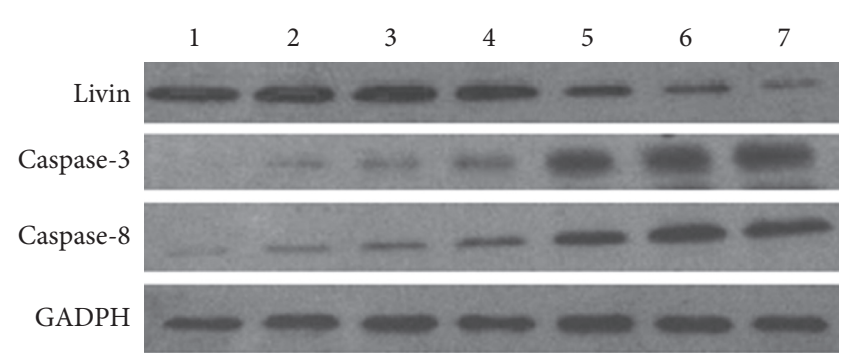

FIgURE 2: Western blots of Livin, caspase-3, and caspase- 8 in OVCA-433 cells. No. 1, blank group; no. 2, shRNA-Livin group; no. 3, shRNA-Livin-NMB group; no. 4, shRNA-Livin-TMB group; no. 5, shRNA-Livin + US group; no. 6, shRNA-Livin-NMB + US group; no. 7 , shRNA-Livin-TMB + US group.

this disease after surgery or chemotherapy [22]. The low survival rate is mainly associated with postoperative complications [23] and cancer drug resistance [24]. Ovarian cancer cell line OVCA-433 ranks first among drug-resistant 
TABLE 3: The protein expression levels of Livin, caspase-3, and caspase-8 in each group.

\begin{tabular}{|c|c|c|c|}
\hline Group & Livin & Caspase-3 & Caspase-8 \\
\hline Blank & $2.71 \pm 0.35^{(2)}$ & $0.12 \pm 0.02^{2}$ & $0.35 \pm 0.08^{(2)}$ \\
\hline shRNA-Livin & $2.54 \pm 0.31^{2}$ & $0.16 \pm 0.04^{(2)}$ & $0.49 \pm 0.15^{(2)}$ \\
\hline shRNA-Livin-NMB & $2.49 \pm 0.28^{(2)}$ & $0.18 \pm 0.04^{(2)}$ & $0.55 \pm 0.11^{(2)}$ \\
\hline shRNA-Livin-TMB & $2.30 \pm 0.33^{(1)(2)}$ & $0.22 \pm 0.06^{(1)(2)}$ & $0.71 \pm 0.18^{(1)(2)}$ \\
\hline shRNA-Livin + US & $1.68 \pm 0.21^{\text {(1) (2) }}$ & $0.96 \pm 0.14^{\text {(1) (2) }}$ & $1.43 \pm 0.20^{(1)(2)}$ \\
\hline shRNA-Livin-NMB + US & $1.35 \pm 0.18^{(1)(2)}$ & $1.21 \pm 0.29$ & $1.85 \pm 0.27^{(1)(2)}$ \\
\hline shRNA-Livin-TMB + US & $0.82 \pm 0.13^{(1)}$ & $1.94 \pm 0.37^{(1)}$ & $2.50 \pm 0.33^{(1)}$ \\
\hline
\end{tabular}

${ }^{1} \mathrm{P}<0.05$ compared to the blank group; ${ }^{2} \mathrm{P}<0.05$ compared to the shRNA-Livin-TMB + US group.

cell lines, and its drug resistance index is higher than 300 presented in $75 \%$ of drugs [25].

Excessive cell proliferation and slow apoptosis caused by abnormal cell cycle regulation play an important role in the occurrence and development of tumors. Cell apoptosis and caspase activation pathway mediate cell death, and this process is performed by various proteins [26]. Livin is a member of the IAP family. It is a functional inhibitor of apoptosis and a structure-related protein, acting as an endogenous inhibitor of apoptosis. Reducing the activity of the IAP family to induce tumor cell apoptosis has become a research hotspot in the field of gene therapy in tumor and cancer [27]. Hendruschk et al. mentioned that low expression of antiapoptotic survivin through RNA interference technology induced glioma cell apoptosis and damaged cell proliferation [28]. A study reported by Lv et al. revealed that inhibition of Livin using RNA interference technology contributed to the apoptosis of leukemia cell line K562 [29]. However, RNA interference technology has the problems of low transfection rate in the vector gene and poor specific targeting, which seriously affects the effect of gene therapy in tumor. Therefore, exploring stable transfection methods with high transfection efficiency, selectivity, and specificity is the key to improve gene therapy.

In recent years, with the development of treatment technology and the emergence of targeted ultrasound contrast agents developing specificity in the target area, microbubbles have become an interesting carrier in gene and drug delivery for tumor and cancer treatment [30,31]. In this study, 7 cell groups with different treatments were involved in this experiment. This study focused on the effects of the group receiving lipid microbubbles targeting Livin gene as the ultrasound contrast agent in the proliferation and apoptosis of ovarian cancer cell line OVCA-433. The results showed that, after cell culture at $24 \mathrm{~h}, 48 \mathrm{~h}$, and $72 \mathrm{~h}$, the cell group receiving ultrasound-targeted microbubble destruction revealed a significant lower cell survival rate than in other 6 cell groups. In addition, after $48 \mathrm{~h}$ of cell culture, the cell apoptosis rate in this group was significantly higher compared to other 6 cell groups. It was suggested that ultrasound-targeted microbubble destruction contributed to effective inhibition of Livin in ovarian cancer cells, resulting in accelerating cell apoptosis and reducing cell survival rate. These findings were similar to another study, indicating that overexpression of sirtuin- 3 mediated by targeted microbubble destruction was helpful to inhibit the progression of ovarian cancer [32]. The research presented by Chen et al. pointed out that ultrasound microbubble destruction targeting survivin induced apoptosis of HeLa cells in cervical cancer and led to inhibit the progression of cervical cancer [33].

At present, it is considered that apoptosis is mainly mediated by two signal pathways, including the death receptor signal pathway [34] and mitochondria-independent signal pathway [35]. Caspase- 3 is identified as a key mediator of apoptosis in neuronal cells in the death receptor pathway and mitochondria-independent pathway [36]. Caspase-8 is the key to the regulation and activation of cell death mediated by the death receptor signal pathway [37]. In general, the antiapoptotic activity of Livin is mediated by inhibiting caspase. Western blot analysis in this study manifested that, compared to the remaining groups, remarkable low expression of Livin mRNA and Livin protein was found in the cell group treated with ultrasound-targeted microbubble destruction; besides, this group indicated significant overexpression of caspase- 3 and caspase- 8 mRNA as well as protein. The findings revealed that the antiapoptotic activity of Livin was negatively correlated with the expression of caspase- 3 and caspase-8. Ultrasound-targeted microbubble destruction accelerated the apoptosis of ovarian cancer OVCA- 433 cells by upregulating the expression of caspase- 3 and caspase-8. In the research of prostatic cancer, Gu et al. suggested that excessive expression of Livin was found in prostatic cancer tissue, and its expression was negatively correlated with caspase-3 expression [38]. A similar study reported by Jin et al. revealed that, after irradiation, significant higher activity of caspase- 3 and caspase- 8 , and low expression of Ki67, survivin and Livin were found in the lung carcinoma xenografts [39]. All these findings demonstrated that Livin was negatively correlated with caspase- 3 and caspase-8.

In summary, ultrasound-targeted microbubble destruction targeting Livin has been proven as an effective approach to inhibit proliferation and induce apoptosis of ovarian cancer cells. The antiapoptotic activity of Livin was associated with expressions of caspase- 3 and caspase- 8 . However, due to the low entrapment efficiency of targeted microbubbles, recombinant plasmid was added into the cultured ovarian cancer cell. For further investigation, addition of different concentrations of microbubbles and exposure to different intensities and times of ultrasound, such as $0.5,1.0$, and $1.5 \mathrm{~W} / \mathrm{cm}^{2}$ and 8,30 , and $50 \mathrm{~s}$, in more than single ovarian cancer cell line were required for the application of UTMD in gene therapy of ovarian cancer. 


\section{Data Availability}

The data used to support the findings of this study are included within the article.

\section{Conflicts of Interest}

The authors declare that there are no conflicts of interest regarding the publication of this article.

\section{References}

[1] P. M. Webb, S. J. Jordan, and S. J. Jordan, "Epidemiology of epithelial ovarian cancer," Best Practice \& Research Clinical Obstetrics \& Gynaecology, vol. 41, pp. 3-14, 2017.

[2] J. Ferlay, I. Soerjomataram, R. Dikshit et al., "Cancer incidence and mortality worldwide: sources, methods and major patterns in GLOBOCAN 2012," International Journal of Cancer, vol. 136, no. 5, pp. E359-E386, 2015.

[3] C. Stewart, C. Ralyea, S. Lockwood, and S. Lockwood, "Ovarian cancer: an integrated review," Seminars in Oncology Nursing, vol. 35, no. 2, pp. 151-156, 2019.

[4] J. Chien, E. M. Poole, and E. M. Poole, "Ovarian cancer prevention, screening, and early detection," International Journal of Gynecological Cancer, vol. 27, pp. S20-S22, 2017.

[5] H.-M. Lu, S. Li, M. H. Black et al., "Association of breast and ovarian cancers with predisposition genes identified by largescale sequencing," JAMA Oncology, vol. 5, no. 1, pp. 51-57, 2019.

[6] A. N. Vargas, "Natural history of ovarian cancer," Ecancermedicalscience, vol. 8, p. 465, 2014.

[7] A. Mallen, T. R. Soong, M. K. Townsend et al., "Surgical prevention strategies in ovarian cancer," Gynecologic Oncology, vol. 151, no. 1, pp. 166-175, 2018.

[8] A. Llueca, A. Serra, K. Maiocchi et al., "Predictive model for major complications after extensive abdominal surgery in primary advanced ovarian cancer," International Journal of Women's Health, vol. 11, pp. 161-167, 2019.

[9] I. Vergote, C. G. Tropé, F. Amant et al., "Neoadjuvant chemotherapy or primary surgery in stage IIIC or IV ovarian cancer," New England Journal of Medicine, vol. 363, no. 10, pp. 943-953, 2010.

[10] M. R. Mirzaei, A. Najafi, M. K. Arababadi, M. H. Asadi, S. J. Mowla, and S. J. Mowla, "Altered expression of apoptotic genes in response to OCT4B1 suppression in human tumor cell lines," Tumor Biology, vol. 35, no. 10, pp. 9999-10009, 2014.

[11] E. Moravcikova, E. Krepela, J. Prochazka et al., "Down-regulated expression of apoptosis-associated genes APIP and UACA in non-small cell lung carcinoma," International Journal of Oncology, vol. 40, pp. 2111-2121, 2012.

[12] Q. L. Deveraux, J. C. Reed, and J. C. Reed, "IAP family proteins---suppressors of apoptosis," Genes \& Development, vol. 13, no. 3, pp. 239-252, 1999.

[13] S. Fulda, "Tumor resistance to apoptosis," International Journal of Cancer, vol. 124, no. 3, pp. 511-515, 2009.

[14] F. H. Igney, P. H. Krammer, and P. H. Krammer, "Death and anti-death: tumour resistance to apoptosis," Nature Reviews Cancer, vol. 2, no. 4, pp. 277-288, 2002.

[15] J. Gao, W. Han, Y. He et al., "Livin promotes tumor progression through YAP activation in ovarian cancer," American journal of cancer research, vol. 10, pp. 3179-3193, 2020.

[16] C.-H. Hsieh, Y.-J. Lin, C.-P. Wu et al., "Livin contributes to tumor hypoxia-induced resistance to cytotoxic therapies in glioblastoma multiforme," Clinical Cancer Research, vol. 21, no. 2, pp. 460-470, 2015.

[17] A. de Leon, R. Perera, P. Nittayacharn et al., "Ultrasound contrast agents and delivery systems in cancer detection and therapy," Advances in Cancer Research, vol. 139, pp. 57-84, 2018.

[18] T. Faez, M. Emmer, K. Kooiman et al., "20 years of ultrasound contrast agent modeling," IEEE Transactions on Ultrasonics, Ferroelectrics, and Frequency Control, vol. 60, pp. 7-20, 2013.

[19] K. P. Pancholi, U. Farook, R. Moaleji, E. Stride, M. J. Edirisinghe, and M. J. Edirisinghe, "Novel methods for preparing phospholipid coated microbubbles," European Biophysics Journal, vol. 37, no. 4, pp. 515-520, 2008.

[20] H. Lin, J. Chen, C. Chen, and C. Chen, "A novel technology: microfluidic devices for microbubble ultrasound contrast agent generation," Medical, \& Biological Engineering \& Computing, vol. 54, no. 9, pp. 1317-1330, 2016.

[21] L. Kuroki, S. R. Guntupalli, and S. R. Guntupalli, "Treatment of epithelial ovarian cancer,” BMJ, vol. 371, p. m3773, 2020.

[22] W.-L. Yang, Z. Lu, R. C. Bast, and R. C. Bast, "The role of biomarkers in the management of epithelial ovarian cancer," Expert Review of Molecular Diagnostics, vol. 17, no. 6, pp. 577-591, 2017.

[23] A. L. Dinca, R. D. Birla, V. G. Dinca et al., "Prognostic factors in advanced ovarian cancer - a clinical trial," Chirurgia, vol. 115, no. 1, pp. 50-62, 2020.

[24] L. Norouzi-Barough, M. R. Sarookhani, M. Sharifi et al., "Molecular mechanisms of drug resistance in ovarian cancer," Journal of Cellular Physiology, vol. 233, no. 6, pp. 4546-4562, 2018.

[25] A. Fernando, S. Glaysher, M. Conroy et al., "Effect of culture conditions on the chemosensitivity of ovarian cancer cell lines," Anti-Cancer Drugs, vol. 17, no. 8, pp. 913-919, 2006.

[26] A. D. Schimmer, "Inhibitor of apoptosis proteins: translating basic knowledge into clinical practice," Cancer Research, vol. 64, no. 20, pp. 7183-7190, 2004.

[27] B. Yan, "Research progress on Livin protein: an inhibitor of apoptosis," Molecular and Cellular Biochemistry, vol. 357, no. 1-2, pp. 39-45, 2011.

[28] S. Hendruschk, R. Wiedemuth, A. Aigner et al., "RNA interference targeting survivin exerts antitumoral effects in vitro and in established glioma xenografts in vivo," Neuro-Oncology, vol. 13, no. 10, pp. 1074-1089, 2011.

[29] J. Lv, Z. P. Qin, M. F. Zheng, Z. C. Chen, Z. Wang, and $Z$. Wang, "In vitro application of RNA interference to silence livin gene expression to induce apoptosis in leukemia cells," European Review for Medical and Pharmacological Sciences, vol. 19, pp. 4390-4396, 2015.

[30] W. K. Chong, V. Papadopoulou, P. A. Dayton, and P. A. Dayton, "Imaging with ultrasound contrast agents: current status and future," Abdominal Radiology, vol. 43, no. 4, pp. 762-772, 2018.

[31] I. D. Gkegkes, C. Iavazzo, and C. lavazzo, "Contrast enhanced ultrasound (CEU) using microbubbles for sentinel lymph node biopsy in breast cancer: a systematic review," Acta Chirurgica Belgica, vol. 115, no. 3, pp. 212-218, 2015.

[32] L. Cheng, D. Zhang, and W. Yan, "Ultrasoundtargeted microbubble destructionmediated overexpression of Sirtuin 3 inhibits the progression of ovarian cancer," Oncology Reports, vol. 46, 2021.

[33] Z. Chen, K. Liang, M. Xie et al., "Novel ultrasound-targeted microbubble destruction mediated short hairpin RNA plasmid transfection targeting survivin inhibits gene expression 
and induces apoptosis of HeLa cells," Molecular Biology Reports, vol. 36, no. 8, pp. 2059-2067, 2009.

[34] N. Singh, Y. G. Lee, O. Shestova et al., "Impaired death receptor signaling in leukemia causes antigen-independent resistance by inducing CAR T-cell dysfunction," Cancer Discovery, vol. 10, no. 4, pp. 552-567, 2020.

[35] K. Sinha, J. Das, P. B. Pal, P. C. Sil, and P. C. Sil, "Oxidative stress: the mitochondria-dependent and mitochondria-independent pathways of apoptosis," Archives of Toxicology, vol. 87, no. 7, pp. 1157-1180, 2013.

[36] F. Yin, H. Zhou, Y. Fang et al., "Astragaloside IV alleviates ischemia reperfusion-induced apoptosis by inhibiting the activation of key factors in death receptor pathway and mitochondrial pathway," Journal of Ethnopharmacology, vol. 248, Article ID 112319, 2020.

[37] B. Tummers, D. R. Green, and D. R. Green, "Caspase-8: regulating life and death,” Immunological Reviews, vol. 277, no. 1, pp. 76-89, 2017.

[38] J. Gu, L. Ren, X. Wang, C. Qu, Y. Zhang, and Y. Zhang, "Expression of livin, survivin and caspase-3 in prostatic cancer and their clinical significance," International Journal of Clinical and Experimental Pathology, vol. 8, pp. 14034-14039, 2015.

[39] Q. Jin, C. Lin, X. Zhu et al., "125I seeds irradiation inhibits tumor growth and induces apoptosis by Ki-67, P21, survivin, livin and caspase- 9 expression in lung carcinoma xenografts," Radiation Oncology, vol. 15, no. 1, p. 238, 2020. 